\title{
SINGLE-INCISION VIDEOLAPAROSCOPIC APPENDECTOMY WITH CONVENTIONAL VIDEOLAPAROSCOPY EQUIPMENT
}

\author{
Videoapendicectomia por incisão única com material de videolaparoscopia convencional
}

\author{
Rodrigo Nascimento PINHEIRO, Renato Costa SOUSA, Fernanda Mesquita de Brito CASTRO, \\ Roberta Oliveira de ALMEIDA, Gustavo de Castro GOUVEIA, Viviane Rezende de OLIVEIRA
}

From the Instituto de Cirurgia Oncológica e Digestiva-ICOD e Instituto de Tumores de Brasília - ITB (Institute of Oncologic and Digestive Surgery and Institute of Tumors of Brasília), Brasília, DF, Brazil

HEADINGS - Laparoscopy. Appendectomy. Appendicitis. Minimally invasive surgery.
ABSTRACT - Background: Acute appendicitis is the most common surgical emergency in daily practice, and is approached laparoscopically in many centers. Efforts have been undertaken for the development of minimally invasive techniques that reduce tissue trauma and offer improved cosmetic results, one of such being the singleincision laparoscopic surgery (SILS). Aim: To present a minimally invasive technique for appendectomy (SILS) undertaken with conventional instruments. Method: Eleven patients were treated in the emergency care center presenting abdominal pain in the right iliac fossa that was suggestive of appendicitis. Diagnostic investigation was subsequently conducted, including physical examination, laboratory and imaging exams (CT scan with intravenous contrast or total abdominal ultrasound), and the results were consistent with acute appendicitis. Thus, after consent, these patients underwent SILS appendectomy under general anesthesia with three trocars (two $10 \mathrm{~mm}$ and one 5 $\mathrm{mm})$, using conventional and optical laparoscopic tweezers $\left(10 \mathrm{~mm}, 30^{\circ}\right)$. The base and pedicle of the appendix were ligated with titanium LT 400 clips. The procedure occurred uneventfully. Inclusion criteria were absence of diffuse peritonitis, BMI (body mass index) less than 35 and absence of serious comorbidities or sepsis. Results: Seven men and four women were operated with average age of 25.7 years and underwent appendectomy through this technique. Mean procedure duration was of 37.2 min. Regarding surgical findings, three had appendicitis in stage 1 , four in stage 2 and four in stage 3 . All patients improved well, without surgical complications, and did not require conversion to open surgery or conventional laparoscopy technique. Conclusion: Appendectomy conducted through Single Incision Laparoscopic Surgery is a feasible and promising technique that can be performed with conventional laparoscopic instruments.

\section{Correspondence:}

Renato Costa Sousa ou Rodrigo N Pinheiro E-mails: renato.costa.sousa@hotmail.com and rodrigo@cancerdf.com.br

Financial source: none

Conflicts of interest: none

Received for publication: 10/09/2013 Accepted for publication: 10/12/2013

DESCRTORES Laparoscópica.
RESUMO - Racional: Apendicite aguda é a emergência cirúrgica mais comum na prática diária, sendo em muitos centros, abordada por laparoscopia. Esforços têm sido voltados para o desenvolvimento de técnicas minimamente invasivas, reduzindo o trauma tecidual e melhorando os resultados cosméticos, dentre essas, a "single incision laparoscopic surgery" (SILS). Objetivo: Apresentar técnica minimamente invasiva para apendicectomia com incisão única e com instrumentos convencionais. Método: Onze pacientes foram atendidos em serviço de emergência devido à dor abdominal em fossa ilíaca direita sugestiva de apendicite. Procedeu-se a investigação diagnóstica, incluindo exames físico, laboratoriais e de imagem (tomografia computadorizada com contraste venoso ou ecografia de abdome total), cujos resultados foram compatíveis com apendicite aguda. Assim, após consentimento, esses pacientes foram submetidos à apendicectomia por SILS, sob anestesia geral, com dois trocárteres de $10 \mathrm{~mm}$ e um de $5 \mathrm{~mm}$, com uso de pinças laparoscópicas convencionais e ótica de $10 \mathrm{~mm}$ e $30^{\circ}$. A base e o pedículo do apêndice foram ligados com clipes de titânio LT 400, sem intercorrências. Critérios de inclusão foram pacientes com apendicite aguda mas sem peritonite generalizada com índice de massa corpórea menor que 35 e ausência de comorbidades graves e ou sepse. Resultados: Foram operados sete homens e quatro mulheres com idade média de 25,7 anos com esta técnica. A duração média do procedimento foi de 37,2 min. Em relação aos achados cirúrgicos, três pacientes apresentavam apendicite em fase 1, quatro em fase 2 e quatro em fase 3. Todos evoluíram bem, sem complicações cirúrgicas e não houve necessidade de conversão da operação para técnica aberta ou mesmo para laparoscopia convencional. Conclusão: Apendicectomia por "single Incision Laparoscopic Surgery" é técnica viável e promissora, podendo ser realizada com instrumentos da laparoscopia convencionais. 
INTRODUCTION

aparoscopic appendectomy, due to its advantages over open techniques, is considered the gold standard treatment for acute appendicitis in many centers ${ }^{3,11,12}$. Since the introduction of the laparoscopic approach, efforts have been directed towards the development of minimally invasive techniques that can reduce the number and size of ports, decrease tissue trauma and improve cosmetic outcomes ${ }^{9}$.

Single Incision Laparoscopic Surgery (SILS) is a new technique that uses a single incision, preferably in the navel, to perform laparoscopic operations without the need for additional incisions. This new method has been used in a wide variety of laparoscopic procedures, including tubal ligation ${ }^{26}$, hysterectomy ${ }^{14}$, appendectomy ${ }^{7,19}$, cholecystectomy ${ }^{13}$, gastrectomy ${ }^{18}$, colectomy ${ }^{4}$ and nephrectomy ${ }^{17}$. Some advantages have been observed with the use of a single incision, such as reduction of postoperative pain and of the complications involving tissue damage at the incision sites and better cosmetic results ${ }^{5}$.

A number of different pieces of equipment and materials have been used to facilitate and/or enable the use of this technical arrangement, but are not essential or indispensable for it.

The objective of this paper is to present the technique and preliminary results of the use of SILS in patients with acute appendicitis using conventional laparoscopic materials and instruments.

\section{METHOD}

Eleven patients, seven men and three women, with mean age of 25.7 years (12-44), were treated between May 2010 and January 2011 for abdominal pain in the right iliac fossa suggestive of appendicitis. Diagnostic investigation was conducted with physical, laboratory and imaging tests. Physical examination was performed with abdominal palpation and searching for the presence of the Blumberg sign or of abdominal pain without irritation. The clinical tests requested to confirm the diagnosis or rule out differential hypotheses included EAS, CBC, beta-HCG (in women of childbearing age), electrolytes and coagulation tests. The imaging exams requested included: total abdominal ultrasound and/or the abdomen and pelvis $\mathrm{CT}$ with intravenous contrast.

Patient selection criteria were adopted in order to avoid increased operating time and maintain safety. They were: absence of diffuse peritonitis, BMI (body mass index) of less than 35 and absence of comorbidities, or sepsis.

\section{Surgical technique}

All patients were operated under general anesthesia. The access of choice was through the umbilicus, with intraumbilical linear or italic " $\mathrm{S}$ " incision, the latter providing for greater skin flexibility and triangulation area. Two 10-mm trocars were used (one $10 \mathrm{~mm}$ and one $5 \mathrm{~mm}$ ), as well as conventional and optical laparoscopic tweezers ( $30^{\circ}$ and $10 \mathrm{~mm}$, Figure 1). Pneumoperitoneum was performed by closed technique. After the incision (straight or " $\mathrm{S}$ "), circular subcutaneous periumbilical areas and areas close to the aponeurosis were dissected, where the trocars were introduced through direct puncturing of the area (providing for better room for the instruments and greater triangulation). The peritoneal cavity was investigated and the diagnosis was confirmed. The appendix was seized by the left hand of the surgeon and the pedicle was subsequently dissected, with release of adhesions and the peritoneum. The base and pedicle of the appendix were ligated with LT 400 titanium clips (Figure 2). After resection of the specimen, it was accommodated in a bag made from latex glove. Once the specimen was removed, hygiene and hemostasis were performed. If deemed necessary, the closure of the aponeurosis was performed within its $10 \mathrm{~mm}$ puncture sites, with subsequent closure of the skin and simple stitching using the surgeon's thread of preference. Dressing was made with a small bundle of gauze and tape.

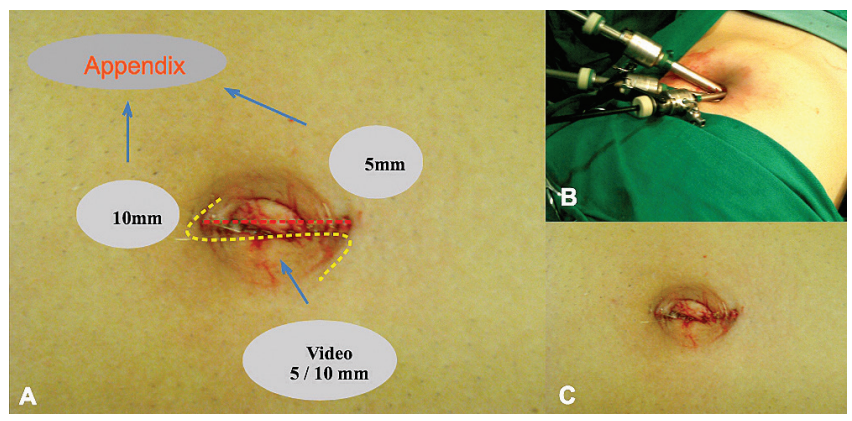

FIGURE 1 - A) Position of the trocars throughout linear or italic "S" single umbilical incision; B) photograph of trocars in position; C) immediate aspect of the surgical wound

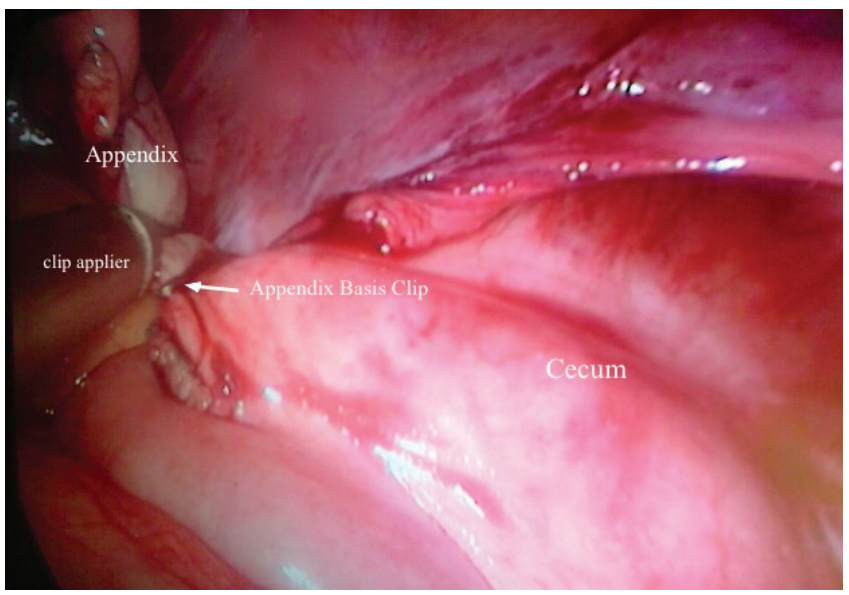

FIGURE 2 - Clamping of the appendix.

Surgical time, complications and adverse findings were noted. 


\section{RESULTS}

Physical examination showed abdominal pain with peritoneal irritation signs in all patients. The results of medical tests were consistent with acute appendicitis, with differential diagnoses such as urinary infection and topical or ectopic pregnancy being ruled out. The imaging tests showed signs suggestive of acute appendicitis or inflammation in the right iliac fossa.

Regarding surgical findings and data, three patients presented appendicitis in stage 1 , four in stage 2 and four in stage 3 . All patients progressed well without complications, except for two surgical wound infections in patients under stage 3 (which were compatible with cavity infection already contracted). There was no need for conversion to laparotomy or even for conventional laparoscopic procedure (Table 1, Figure 1).

TABLE 1 - Characteristics of patients undergoing SILS appendectomy

\begin{tabular}{|c|c|c|c|c|}
\hline Gender & $\begin{array}{c}\text { Age } \\
\text { (years) }\end{array}$ & $\begin{array}{l}\text { Operation } \\
\text { time (min) }\end{array}$ & $\begin{array}{c}\text { Stage of } \\
\text { appendicitis }\end{array}$ & Complications \\
\hline Female & 20 & 40 & 1 & -- \\
\hline Male & 15 & 40 & 2 & -- \\
\hline Male & 39 & 50 & 3 & -- \\
\hline Female & 20 & 35 & 2 & -- \\
\hline Female & 38 & 35 & 1 & -- \\
\hline Male & 44 & 40 & 3 & $\begin{array}{l}\text { Surgical wound } \\
\text { infection }\end{array}$ \\
\hline Male & 13 & 35 & 2 & -- \\
\hline Male & 13 & 35 & 3 & $\begin{array}{l}\text { Surgical wound } \\
\text { infection }\end{array}$ \\
\hline Male & 40 & 35 & 3 & -- \\
\hline Male & 12 & 30 & 1 & -- \\
\hline Female & 29 & 35 & 2 & -- \\
\hline
\end{tabular}

\section{DISCUSSION}

Acute appendicitis is the most common surgical emergency in daily practice. The disease can occur at any age and requires surgical treatment in all diagnosed cases. Depending on inflammatory findings, appendicitis can be classified into Grade 0 (normal); 1 (hyperemia and edema); 2 (fibrinous exudate); 3 (segmental necrosis); 4A (abscess); 4B (regional peritonitis); 4C (necrosis of the appendix base); 5 (diffuse peritonitis) $^{8}$. The operation is often performed laparoscopically because of its advantages when compared to laparotomy, such as greater diagnostic accuracy, reduced risk of surgical wound infection, shorter hospital stays, patients enjoying faster return to daily life, lower incidence of adynamic ileus and lower risk of incisional hernia ${ }^{10,22}$. These risks are even lower if a single incision is used. This is the reason for the increased interest in even less invasive techniques in various surgical procedures, including
SILS appendectomy ${ }^{25}$.

Pelosi et al. ${ }^{15}$, in 1992, first described a singleincision laparoscopic appendectomy on a child. Valla et al. ${ }^{23}$ in 1997 presented a case series of 200 pediatric patients who underwent using single-incision laparoscopic appendectomy with externalization of the appendix. Ates et al. ${ }^{1}$, in 2007, described a fully intra-abdominal single-incision appendectomy technique. Since then, many technical variants have been described but there is still no established standard.

The recent interest in SILS has led many surgeons to use existing conventional tools when performing single-incision laparoscopies and, in turn, the industry has developed a large variety of new tools to facilitate these procedures. Some types of ports are already being marketed, such as the TriPort (Advanced Surgical Concepts, Wicklow, Ireland), the SILS port (Covidien, Norwalk, Conn.), the Uni-X Single Port System (Pnavel Systems, Inc., Morganville, New Jersey), the Anchorport (Surgiquest Inc., Orange) and the Gelport (Applied Medical, Rancho Santa Margarita, California) ${ }^{6}$. However, it has been observed that SILS can be accomplished with existing technology and without the need for new instruments by surgeons with experience in conventional laparoscopy or who have received specific training or expertise.

The biggest challenge to be overcome in SILS is to avoid conflict between the instruments and optics and to reduce stress during surgery, the latter caused by the limited space offered by a single incision, which makes the work of the surgeon and his assistant harder. For this reason, some studies have been proposed using endoscopic cameras and semiflexible tweezers, making the procedure supposedly more comfortable ${ }^{9}$. In addition, there are some difficulties or problems in accessing the abdominal cavity using a single incision, such as small umbilical rings, high $\mathrm{BMI}$, adhesions from previous operations, availability of the port, lack of angled instruments, the short length of the instruments, inadequate imaging, small incision for the extraction of the specimen, and leaks in the pneumoperitoneum ${ }^{20}$.

The advantages of SILS appendectomy are primarily related to better cosmetic results due to the reduced number of skin incisions. A single incision is made on a natural scar - the umbilicus - with results almost invisible a few months after surgery, preserving the patient's body image. Furthermore, it is believed that SILS provides less postoperative pain by eliminating muscle damage and reducing tissue damage due to the non-introduction of other ports, in addition to presenting less risk of bleeding of the epigastric vessel ${ }^{2,16,21,24}$.

In this initial study, it was observed that it was possible to perform the procedure with existing materials and equipment in a timely and safe manner, provided that it be performed by experienced staff. 
It is worth highlighting that selection criteria were adopted for this initial group of patients in order to avoid increased operating time and maintain safety. They were: absence of diffuse peritonitis, body mass index of less than 35 and absence of comorbidities and/or sepsis.

\section{CONCLUSION}

SILS appendectomy is a feasible and promising procedure, and can be performed with conventional laparoscopic instruments.

\section{REFERENCES}

1. Ates O et al (2007) "Single-port laparoscopic appendectomy conducted intracorporeally with the aid of a transabdominals ling suture". J Pediatr Surg 42:1071-1074

2. BarryM,WinterDC."Laparoscopic port site hernias: any port inastormorastorminanyport?".AnnSurg.2008;248:687-9.

3. Bresciani C, Perez RO, Habr-Gama A, Jacob CE, Ozaki A, Batagello C, Proscurshim I, Gama-Rodrigues J. "Laparoscopic versus standard appendectomy outcomes and cost comparisons in the private sector". J Gastrointest Surg 2005; 9: 1174-1180; discussion 1180-1181

4. Bucher $P$, Pugin F., e Morel $P$, "Single port access laparoscopic right hemicolectomy," International Journal of Colorectal Disease, vol. 23, no. 10, pp. 1013-1016, 2008. P.

5. Chow A, Aziz O, Purkayastha S, Darzi A, e Paraskeva P. "Single Incision Laparoscopic Surgery for Acute Appendicitis: Feasibility in Pediatric Patients". Diagnostic and Therapeutic Endoscopy, vol. 2010

6. Derweesh I H, Silberstein J L, Bazzi W, Kopp R, Downs T M e Kanel C J "Laparo-Endoscopic Single-Site Surgery for Radical and Cytoreductive Nephrectomy, Renal Vein Thrombectomy, and Partial Nephrectomy: A Prospective Pilot Evaluation" Diagnostic and Therapeutic Endoscopy, Volume 2010, Article ID 107482

7. Esposito C., "One-trocar appendectomy in pediatric surgery," Surgical Endoscopy, vol. 12, no. 2, pp. 177-178, 1998.

8. Gomes C A, Nunes T A. "Classificação laparoscópica da apendicite aguda. Correlação entre graus da doença e as variáveis perioperatórias." Revista do Colégio Brasileiro de Cirurgiões 2006; Volume 33, número 05

9. Hirano $Y$, Watanabe $T$, Uchida $T$, Yoshida $S$, Tawaraya $K$, Kato $H$, Hosokawa. "Single-incision laparoscopic cholecystectomy: Single institution experience and literature review". World J Gastroenterol 2010 January 14; 16(2): 270-274.

10. Keus F, Jong J. A, Gooszen H. G., e Van Laarhoven C. J., "Laparoscopic versus open cholecystectomy for patients with symptomatic cholecystolithiasis," Cochrane Database of Systematic Reviews, no. 4, Article ID CD006231, 2006.
11. Martin LC, Puente I, Sosa JL, Bassin A, Breslaw R, McKenney MG, Ginzburg E, Sleeman D. "Open versus laparoscopic appendectomy. A prospective randomized comparison. "Ann Surg 1995; 222: 256261; discussion 261-262

12. Milewczyk M, Michalik M, Ciesielski M. "A prospective, randomized, unicenter study comparing laparoscopic and open treatments of acute appendicitis". Surg Endosc 2003; 17:1023-1028.

13. Navarra G, Pozza E, Occhionorelli S, Carcoforo P, e Donini I, "Onewound laparoscopic cholecystectomy," British Journal of Surgery, vol. 84, no. 5, p. 695, 1997.

14. Pelosi M.A and Pelosi III M. A, "Laparoscopic supracervical hysterectomy using a single-umbilical puncture (minilaparoscopy)," The Journal of Reproductive Medicine, vol. 37, no. 9, pp. 777-784, 1992.

15. Pelosi MA, Pelosi MA III (1992) "Laparoscopic appendectomyusing a single umbilical puncture (minilaparoscopy)". J ReprodMed 37:588-594

16. Pinheiro et al.,Single Incision Laparoscopic Cholecystectomy: Description of a Series of 30 Cases of Laparoscopic Cholecystectomy Performed Using Conventional Instruments, Bras. J. Video-Sur, 2011, v. 4, n. 2: 091-095.

17. Rane A, Rao P,e Rao P, "Single-port-access nephrectomy and other laparoscopic urologic procedures using a novel laparoscopic port (R-port)," Urology, vol. 72, no. 2, pp. 260-263, 2008

18. Reavis K. M., Hinojosa M.W, Smith B. R., e Nguyen N. T., "Singlelaparoscopic incision transabdominal surgery sleeve gastrectomy," Obesity Surgery, vol. 18, no. 11, pp. 1492-1494, 2008.

19. Rispoli G, Armellino M. F., e Espósito C, "One-trocar appendectomy: sense and nonsense," Surgical Endoscopy and Other Interventional Techniques, vol. 16, no. 5, pp. 833-835, 2002.

20. Ross S B, Clark C W, Morton C A e Rosemurgy A S, "Access for Laparoendoscopic Single Site Surgery" Diagnostic and Therapeutic Endoscopy Volume 2010, Article ID 943091

21. Saber AA, Meslemani AM, Davis R, Pimentel R. Safety zones for anterior abdominal wall entry during laparoscopy: a CT scan mapping of epigastric vessels. Ann Surg. 2004 Feb;239(2):182-5.

22. Tsao K. J., St Peter S. D., Valusek P. A., et al., "Adhesive small bowel obstruction after appendectomy in children: comparison between the laparoscopic and open approach," Journal of Pediatric Surgery, vol. 42, no. 6, pp. 939-942, 2007

23. Valla J et al (1999) "Umbilical one-puncture laparoscopic assisted appendectomy in children." Surg Endosc 13:83-85

24. Veldkamp R, Kuhry E, Hop WC, Jeekel J, Kazemier G, Bonjer HJ, Haglind $E$, Påhlman L, Cuesta MA, Msika S, Morino M, Lacy AM; COlon cancer Laparoscopic or Open Resection Study Group (COLOR). Laparoscopic surgery versus open surgery for colon cancer: short-term outcomes of a randomised trial. Lancet Oncol. 2005 Jul;6(7):477-84..

25. Vidal O, Valentini M, Ginestà C, Benarroch G, García-Valdecasas JC."Apendicectomía laparoscópica urgente com uma solaincisiónu mbilical(SILS):experiencia inicial". Cir Esp, Maio 2009; 85(5):317-9

26. Wheeless Jr. C.R, "Outpatient laparoscope sterilization under local anesthesia, "Obstetrics and Gynecology, vol. 39, no. 5, pp. 767770, 1972. 